\title{
Pengembangan Cookies Non Terigu dari Campuran Tepung Beras, Tepung Tapioka, dan Tepung Maizena
}

\author{
Yunda Maymanah Rahmadewi ${ }^{\mathrm{a}, 1, *}$, Silmi Sabila ${ }^{\mathrm{b}, 2}$ \\ ${ }^{a}$ Bisnis Jasa Makanan UAD, Jl. Pramuka No 42 Yogyakarta, 55161, Indonesia \\ b Bisnis Jasa Makanan UAD, Jl. Pramuka No 42 Yogyakarta, 55161, Indonesia \\ 1 yunda.maymanah@culinary.uad.ac.id, ${ }^{2}$ silmisabila3@gmail.com \\ * penulis korespondensi
}

\begin{abstract}
Several flour usage which is often found inside such as rice flour, tapioca flour, and cornstarch is limited to a single usage on simple processing. The purpose of this study was to determine the formulation and ratio of rice flour, tapioca flour, and cornstarch as raw material for cookies. In addition, this study aims to reveal the nutritional value of non-flour cookies.

The study used a complete randomized design with 3 times replication with factors ratio of rice flour, tapioca flour, and cornstarch. The cookies were analyzed for their chemical properties including water content, protein content, fat content, ash content, carbohydrate content, and crude fiber content. The results were statistically analyzed using annova. If the results were different, then proceed with the DMRT test with a significance level of 5\%. Cookies produced were also calculated on the calorific value per serving.

Cookies made from rice flour, tapioca flour, and cornstarch have ash content, fat content, and caloric value consistent with the Indonesian National Standard of similar products, biscuits. While protein content, crude fiber content, and carbohydrate levels were not in consistent with the Indonesian National Standard of biscuits. Cookies with ratio of rice flour, tapioca flour, and cornstarch 65:30:5 was selected for the best cookies because of the highest protein content and sugar content.
\end{abstract}

Keywords: cookies, flour, non-flour, rice flour, cornstarch, tapioca flour

\section{ABSTRAK}

Pemanfaatan tepung yang sering dijumpai di dapur seperti tepung beras, tepung tapioka, dan tepung maizena hanya sebatas pengolahan tunggal pada olahan sederhana. Tujuan dari penelitian ini adalah menentukan formulasi dan perbandingan tepung beras, tepung tapioka, dan tepung maizena sebagai bahan baku cookies. Selain itu, penelitian ini bertujuan untuk menganalisa kandungan gizi dan nilai kalori cookies no terigu tersebut.

Desain penelitian menggunakan rancangan acak lengkap 3 kali ulangan dengan faktor perbandingan tepung beras, tepung tapioka, tepung maizena. Cookies yang dihasilkan selanjutnya dianalisa sifat kimianya antara lain analisa kadar air, kadar protein, kadar lemak, kadar abu, kadar karbohidrat, dan kadar serat kasar. Data dianalisis secara statistik menggunakan annova. Apabila hasil yang diperoleh ada beda nyata, maka dilanjutkan dengan uji DMRT dengan tingkat signifikasi $5 \%$. Cookies yang dihasilkan juga dihitung nilai kalori per sajiannya.

Cookies berbahan baku campuran tepung beras, tepung tapioka, dan tepung maizena memiliki kadar abu, kadar lemak, dan nilai kalori yang sesuai dengan Standar Nasional Indonesia produk sejenis yaitu biskuit. Sedangkan kadar protein, kadar serat kasar, dan kadar karbohidrat belum sesuai dengan Standar Nasional Indonesia biskuit. Formulasi cookies yang dipilih berdasarkan kandungan kimia cookies yaitu campuran tepung beras, tepung tapioka, dan tepung maizena dengan perbandingan 65:30:5 karena memiliki kadar protein paling tinggi.

Kata Kunci: cookies, non terigu, tepung beras, tepung maizena, tepung tapioka, terigu 


\section{Pendahuluan}

Pola konsumsi sebagian masyarakat Indonesia mulai bergeser dari pola konsumsi makanan yang dimasak sendiri ke arah konsumsi makanan jadi yang dijualbelikan. Hal ini didukung dengan hasil Survei Sosial Ekonomi Nasional 2015 (SUSENAS) yang menyebutkan bahwa konsumsi sebagian besar makanan jadi mengalami peningkatan. Masyarakat Indonesia lebih banyak mengkonsumsi berbagai macam makanan basah dibandingkan makanan kering. Namun, kenaikan konsumsi rata-rata kue kering/biskuit/semprong/cookies mengalami kenaikan terbesar kedua (24.22\%) setelah lontong/ketupat sayur $(26.15 \%)$ (Anonim ${ }^{\mathrm{a}}$, 2015). Hal ini menunjukkan adanya peluang pasar cookies yang cukup besar.

Cookies adalah salah satu jenis kue kering yang menggunakan terigu sebagai bahan baku utamanya. Terigu mengandung protein gluten yang tidak dimiliki oleh tepung-tepungan dari keluarga serealia lainnya. Gluten tersebut berperan dalam pembuatan kue karena memudahkan proses pencetakan adonan dan mampu menahan gas yang akan menyusun struktur seperti bunga karang yang kukuh apabila dipanggang (Luh dan Yuan-Kuang, 1980). Namun, dalam pembuatan cookies, proses pembentukan gluten tidak semaksimal pada pembuatan roti dan mie. Sehingga penggunaan terigu bisa digantikan dengan tepung-tepung lainnya yang rendah atau tanpa gluten.

Pentingnya gluten pada olahan tepung terigu tidak selamanya dapat diterima dengan baik oleh tubuh. Beberapa orang dengan autism spectrum disorder (ASD) dan celiac disease tidak dapat menerima gluten yang masuk ke dalam tubuh sehingga dapat menimbulkan sikap temperamental (Risti dan Rahayuni, 2013). Namun, pada umumnya cookies yang berada di pasaran menggunakan terigu sebagai bahan baku utamanya. Sedangkan penggunaan terigu sendiri masih menjadi hal yang sering diperbincangkan karena berkaitan dengan ketahanan pangan Indonesia. Terigu diperoleh dari gandum yang merupakan tanaman yang belum banyak dibudidayakan di Indonesia. Oleh karena itu, Indonesia masih melakukan impor tepung terigu maupun gandum.

Potensi alam Indonesia menghasilkan bahan pangan yang beragam. Aneka ragam bahan pangan baik yang bersifat basah maupun kering banyak ditemukan di dapur setiap rumah. Bahan pangan yang merupakan bahan lokal kering berupa tepung-tepungan hampir tidak lepas dari olahan keluarga. Beberapa jenis tepung seperti tepung beras, tepung tapioka, dan tepung maizena sangat mudah ditemukan di dapur keluarga maupun di warung dan pasar swalayan. Namun, pemanfaatan dan penggunaan tepung-tepung tersebut masih sederhana untuk kebutuhan sehari-hari.

Perkembangan penggunaan ketiga jenis tepung tersebut sudah mulai bergerak ke arah produk pastry and bakery. Montes, etc. (2015) telah mengembangkan cookies yang terbuat dari campuran tepung beras dan tepung tapioka. Tepung maizena juga digunakan sebagai bahan campuran dalam pembuatan cookies non terigu (Adeyeye etc., 2015; Giuberti etc., 2015; Rai etc., 2014). Sedangkan kombinasi ketiga tepung tersebut pernah dikembangkan menjadi roti tawar (bread) gluten free (Ana etc., 2004). Namun, pembuatan cookies menggunakan campuran tepung beras, tepung tapioka, dan tepung maizena belum pernah dilakukan dan diteliti lebih dalam sehingga perlu dilakukan studi terkait topik ini. 


\section{Metode Penelitian}

Penelitian ini menggunakan rancangan acak lengkap dengan faktor yang diamati kandungan kimia cookies berdasarkan formulasi-formulasi campuran tepung beras, tepung tapioka, dan tepung maizena.

\section{Bahan}

Bahan yang digunakan dalam penelitian ini adalah bahan untuk pembuatan cookies dan bahan untuk analisa sifat kimia. Adapun bahan untuk membuat cookies yaitu tepung beras, tepung tapioka, tepung maizena, mentega, gula halus, garam, dan telur ayam negeri yang diperoleh dari toko bahan kue dan pasaw swalayan.

Bahan untuk analisa kimia menggunakan katalisator analisa protein, larutan untuk analisa protein seperti asam sulfat pekat $\left(\mathrm{H}_{2} \mathrm{SO}_{4}\right)$, larutan kalium sulfat $\left(\mathrm{K}_{2} \mathrm{SO}_{4}\right)$, larutan natrium hidroksida $(\mathrm{NaOH})$, natrium thiosulfat $\left(\mathrm{Na}_{2} \mathrm{~S}_{2} \mathrm{O}_{3}\right)$, larutan asam borat jenuh $\left(\mathrm{H}_{3} \mathrm{BO}_{3}\right)$, larutan asam klorida $(\mathrm{HCl}) 0,02 \mathrm{~N}$, larutan petroleum eter untuk analisa lemak.

Memuat uraian tentang bahan dan peralatan, tempat dan waktu penelitian, serta metode penelitian (desain penelitian, perlakuan, rancangan percobaan, metode analisis) yang digunakan.

\section{Metode}

Pembuatan Cookies Non Terigu dari Campuran Tepung Beras, Tepung Tapioka, dan Tepung Maizena

Cookies berbasis campuran tepung beras, tepung tapioka, dan tepung maizena dibuat berdasarkan resep dari Sultan (1969) dan Smith (1972) yang dimodifikasi. Resep dasar cookies dan modifikasi resep untuk cookies berbasis campuran tepung beras, tepung tapioka, dan tepung maizena tersebut dapat dilihat pada Tabel 1. berikut ini.

Tabel 1. Resep dasar cookies dan modifikasi resep cookies non terigu

\begin{tabular}{lcc}
\hline \multirow{2}{*}{ Bahan } & Resep Dasar* & Resep Modifikasi \\
\cline { 2 - 3 } & Jumlah $(\%)$ & Jumlah $(\%)$ \\
\hline Tepung & 100 & 100 \\
\hline Gula halus & 60 & 40 \\
\hline Shortening & 37.5 & 37.5 \\
\hline Telur & 12.5 & 12.5 \\
\hline Susu skim & 3.125 & - \\
\hline Garam & 0.5 & 0.5 \\
\hline Baking powder & 3.125 & - \\
\hline Vanili & 1.56 & - \\
\hline Air & 18.75 & - \\
\hline Coklat bubuk & 5 & - \\
\hline \multicolumn{2}{l}{$*$ Resep dasar dari Sultan (1969) dan Smith (1972) }
\end{tabular}

Sedangkan perbandingan tepung beras, tepung tapioka, dan tepung maizena yang digunakan dalam pengembangan cookies non terigu adalah sebagai berikut: 
Tabel 2. Perbandingan Campuran Tepung Beras, Tepung Tapioka, dan Tepung Maizena Perbandingan Campuran Tepung

\begin{tabular}{cccc}
\cline { 2 - 4 } Jenis Cookies & Tepung Beras (\%) & Tepung Tapioka (\%) & $\begin{array}{c}\text { Tepung Maizena } \\
(\%)\end{array}$ \\
\hline BTM 1 & 45 & 45 & 10 \\
\hline BTM 2 & 50 & 40 & 10 \\
\hline BTM 3 & 55 & 35 & 10 \\
\hline BTM 4 & 60 & 35 & 10 \\
\hline BTM 5 & 60 & 30 & 15 \\
\hline BTM 6 & 60 & 25 & 5 \\
\hline BTM 7 & 65 & 30 & 20 \\
\hline BTM 8 & 55 & 30 &
\end{tabular}

Proses pembuatan cookies menggunakan teknik pencampuran creaming method yaitu teknik penampuran gula dan lemak terlebih dahulu baru dimasukkan dengan bahan kering lainnya. Gula halus dan margarin dicampur hingga rata dengan kecepatan paling rendah selama 1 menit lalu ditambahkan telur dan diaduk hingga rata. Setelah tercampur rata selanjutnya ditambahkan bahan kering dan diaduk menggunakan spatula. Adonan cookies non terigu digiling tipis dan dicetak kemudian dipanggang pada suhu $180^{\circ} \mathrm{C}$ selama $10-15$ menit.

\section{Analisa kimia dan nilai kalori}

Cookies non terigu yang diperoleh selanjutnya dianalisa kandungannya antara lain analisa kadar air, kadar protein, kadar lemak, kadar abu, kadar karbohidrat, dan kadar serat kasar. Analisa kadar air menggunakan metode thermogravimetri, kadar protein menggunakan metode mikrokjeldahl, kadar lemak menggunakan metode soxhlet, kadar abu menggunakan metode pengabuan kering, kadar karbohidrat menggunakan metode by different, serta kadar serat kasar menggunakan hidrolisis asam. Diakhir juga dilakukan perhitungan tentang nilai kalori cookies tersebut per sajian.

\section{Hasil dan Pembahasan}

\subsection{Kadar Protein}

Cookies berbahan baku campuran tepung beras, tepung tapioka, dan tepung maizena mempunyai kadar protein yang lebih rendah dari batas minimal nilai Standar Nasional Indonesia. Berdasarkan Standar Nasional Indonesia (01-2973-1992) kadar protein biskuit adalah minimal 6\% dan hasil analisis kadar protein cookies tersebut antara 2.74-3.40\% (Tabel 3). Cookies berbagai variasi perbandingan tepung beras, tepung tapioka, dan tepung maizena memiliki rentang kadar protein yang sama dengan cookies yang dibuat dari campuran tepung beras dan tepung tapioka 25\%:75\% serta 50\%:50\% (Montes et al., 2015). 
Tabel 3. Kadar Protein Cookies Berbasis Campuran Tepung Beras, Tepung Tapioka, dan Tepung Maizena

\begin{tabular}{cc}
\hline $\begin{array}{c}\text { Jenis } \\
\text { Cookies }\end{array}$ & Kadar Protein (\%) \\
\hline BTM 1 & $2.7434^{\mathrm{a}}$ \\
\hline BTM 2 & $3.1750^{\mathrm{b}, \mathrm{c}, \mathrm{d}}$ \\
\hline BTM 3 & $3.0835^{\mathrm{b}, \mathrm{c}}$ \\
\hline BTM 4 & $3.2749^{\mathrm{d}, \mathrm{e}}$ \\
\hline BTM 5 & $3.3994^{\mathrm{e}}$ \\
\hline BTM 6 & $3.0438^{\mathrm{b}}$ \\
\hline BTM 7 & $3.6129^{\mathrm{f}}$ \\
\hline BTM 8 & $3.2290^{\mathrm{c}, \mathrm{d}}$ \\
\hline BTM 9 & $3.0896^{\mathrm{b}, \mathrm{c}}$ \\
\hline
\end{tabular}

* Notasi yang berbeda menunjukkan hasil yang berbeda nyata dengan tingkat signifikansi 0.05

Cookies dengan perbandingan tepung beras, tepung tapioka, tepung maizena sebesar 45:45:10 memiliki kadar protein paling rendah dan perbandingan 65:35:5 memiliki kadar protein paling tinggi. Peningkatan jumlah tepung beras dan penurunan jumlah tepung maizena menyebabkan peningkatan kadar protein.

\subsection{Kadar Lemak}

Cookies berbahan baku campuran tepung beras, tepung tapioka, dan tepung maizena mempunyai kadar lemak lebih tinggi dari batas minimum nilai Standar Nasional Indonesia. Berdasarkan Standar Nasional Indonesia (01-2973-1992) kadar lemak biskuit adalah minimal 9.5\% dan hasil analisis kadar lemak cookies tersebut antara 17.81-18.66\%. Tabel 4 menunjukkan bahwa kadar lemak cookies dengan berbagai perbandingan tepung beras, tepung tapioka, dan tepung maizena tidak berbeda nyata. Perbedaan komposisi ketiga tepung tidak mempengaruhi kadar lemak total pada cookies yang dihasilkan karena bahan baku ketiga tepung tersebut memiliki jumlah lemak yang relatif sama. 
Tabel 4. Kadar Lemak Cookies Berbasis Campuran Tepung Beras, Tepung Tapioka, dan Tepung Maizena

\begin{tabular}{cl}
\hline $\begin{array}{c}\text { Jenis } \\
\text { Cookies }\end{array}$ & Kadar Lemak (\%) \\
\hline BTM 1 & $18.4885^{\mathrm{a}}$ \\
\hline BTM 2 & $18.3000^{\mathrm{a}}$ \\
\hline BTM 3 & $18.6613^{\mathrm{a}}$ \\
\hline BTM 4 & $17.9422^{\mathrm{a}}$ \\
\hline BTM 5 & $17.8080^{\mathrm{a}}$ \\
\hline BTM 6 & $18.1961^{\mathrm{a}}$ \\
\hline BTM 7 & $18.2574^{\mathrm{a}}$ \\
\hline BTM 8 & $18.2086^{\mathrm{a}}$ \\
\hline BTM 9 & $18.6358^{\mathrm{a}}$ \\
\hline
\end{tabular}

* Notasi yang berbeda menunjukkan hasil yang berbeda nyata dengan tingkat signifikansi 0.05

\subsection{Kadar Karbohidrat}

Cookies berbahan baku campuran tepung beras, tepung tapioka, dan tepung maizena mempunyai kadar karbohidrat yang lebih rendah dari batas minimal nilai Standar Nasional Indonesia. Berdasarkan Standar Nasional Indonesia (01-2973-1992) kadar karbohidrat biskuit adalah minimal $70 \%$ dan hasil analisis kadar karbohidrat cookies tersebut antara 61.93-67.52\% (Tabel 5). Kandungan karbohidrat yang lebih rendah daripada SNI disebabkan oleh kandungan lain yang lebih tinggi seperti kadar serat kasar dan lemak.

Tabel 5. Kadar Karbohidrat Cookies Berbasis Campuran Tepung Beras, Tepung Tapioka, dan Tepung Maizena

\begin{tabular}{cc}
\hline $\begin{array}{c}\text { Jenis } \\
\text { Cookies }\end{array}$ & $\begin{array}{c}\text { Kadar Karbohidrat } \\
(\%)\end{array}$ \\
\hline BTM 1 & $67.5210^{\mathrm{c}}$ \\
\hline BTM 2 & $65.6650^{\mathrm{b}}$ \\
\hline BTM 3 & $65.6217^{\mathrm{b}}$ \\
\hline BTM 4 & $65.7071^{\mathrm{b}}$ \\
\hline BTM 5 & $66.3623^{\mathrm{b}, \mathrm{c}}$ \\
\hline BTM 6 & $62.7578^{\mathrm{a}}$ \\
\hline BTM 7 & $62.4850^{\mathrm{a}}$ \\
\hline BTM 8 & $63.1319^{\mathrm{a}}$ \\
\hline BTM 9 & $61.9302^{\mathrm{a}}$
\end{tabular}

* Notasi yang berbeda menunjukkan hasil yang berbeda nyata dengan tingkat signifikansi 0.05

Cookies dengan perbandingan tepung beras, tepung tapioka, tepung maizena sebesar 50:30:20 memiliki kadar karbohidrat paling rendah dan perbandingan 45:45:10 memiliki kadar karbohidrat paling tinggi. Peningkatan jumlah tepung beras dan penurunan jumlah tepung tapioka menyebabkan penurunan kadar karbohidrat. Penurunan jumlah tepung beras dan peningkatan jumlah tepung maizena tidak menyebabkan perubahan kadar karbohidrat. 


\subsection{Kadar Serat Kasar}

Cookies berbahan baku campuran tepung beras, tepung tapioka, dan tepung maizena mempunyai kadar serat kasar yang lebih tinggi dari batas maksimal nilai Standar Nasional Indonesia. Berdasarkan Standar Nasional Indonesia (01-2973-1992) kadar serat kasar biskuit adalah maksimal $0.5 \%$ sedangkan hasil analisis kadar serat kasar cookies tersebut antara 4.92-9.87\% (Tabel 6). Hal ini menunjukkan cookies tersebut memiliki kandungan serat kasar yang tidak sesuai dengan SNI. Namun, kadar serat kasar tersebut sesuai dengan standar cookies Brasil yaitu minimal 3\% (Montes et al., 2015). Cookies berbahan baku campuran tepung beras, tepung tapioka, dan tepung maizena bisa menjadi kue kering yang lebih menyehatkan karena kandungan serat kasar yang lebih tinggi.

Tabel 6 Kadar Serat Kasar Cookies Berbasis Campuran Tepung Beras, Tepung Tapioka, dan Tepung Maizena

\begin{tabular}{cc}
\hline $\begin{array}{c}\text { Jenis } \\
\text { Cookies }\end{array}$ & $\begin{array}{c}\text { Kadar Serat Kasar } \\
(\%)\end{array}$ \\
\hline BTM 1 & $4.9178^{\mathrm{a}}$ \\
\hline BTM 2 & $6.6350^{\mathrm{a}, \mathrm{b}}$ \\
\hline BTM 3 & $7.5450^{\mathrm{b}, \mathrm{c}}$ \\
\hline BTM 4 & $5.7298^{\mathrm{a}, \mathrm{b}}$ \\
\hline BTM 5 & $6.7408^{\mathrm{a}, \mathrm{b}}$ \\
\hline BTM 6 & $9.4703^{\mathrm{d}}$ \\
\hline BTM 7 & $9.6490^{\mathrm{d}}$ \\
\hline BTM 8 & $8.7570^{\mathrm{c}, \mathrm{d}}$ \\
\hline BTM 9 & $9.8718^{\mathrm{d}}$ \\
\hline
\end{tabular}

* Notasi yang berbeda menunjukkan hasil yang berbeda nyata dengan tingkat signifikansi 0.05

Cookies dengan perbandingan tepung beras, tepung tapioka, tepung maizena sebesar 45:45:10 memiliki kadar protein paling rendah dan perbandingan 50:30:20 memiliki kadar protein paling tinggi. Peningkatan jumlah tepung beras dan penurunan jumlah tepung tapioka menyebabkan peningkatan kadar serat kasar. Kadar serat kasar juga meningkat ketika jumlah tepung maizena bertambah dan jumlah tepung tapioka semakin berkurang.

\subsection{Kadar Abu}

Cookies berbahan baku campuran tepung beras, tepung tapioka, dan tepung maizena mempunyai kadar abu yang lebih rendah dari batas maksimum nilai Standar Nasional Indonesia. Berdasarkan Standar Nasional Indonesia (01-2973-1992) kadar abu biskuit adalah maksimal $2 \%$ dan hasil analisis kadar abu cookies tersebut antara $0.58-1.48 \%$ (Tabel 7). Kadar abu pada cookies yang dihasilkan juga memiliki kadar abu dibawah standar Brasil sebesar 3\% (Montes et al., 2015). 
Tabel 7. Kadar Abu Cookies Berbasis Campuran Tepung Beras, Tepung Tapioka, dan Tepung Maizena

\begin{tabular}{cc}
\hline $\begin{array}{c}\text { Jenis } \\
\text { Cookies }\end{array}$ & Kadar Abu (\%) \\
\hline BTM 1 & $1.3202^{\mathrm{d}, \mathrm{e}}$ \\
\hline BTM 2 & $1.0450^{\mathrm{b}}$ \\
\hline BTM 3 & $1.0118^{\mathrm{b}}$ \\
\hline BTM 4 & $1.0839^{\mathrm{b}, \mathrm{c}}$ \\
\hline BTM 5 & $1.1996^{\mathrm{b}, \mathrm{c}, \mathrm{d}}$ \\
\hline BTM 6 & $1.0847^{\mathrm{b}, \mathrm{c}}$ \\
\hline BTM 7 & $0.5793^{\mathrm{a}}$ \\
\hline BTM 8 & $1.4853^{\mathrm{e}}$ \\
\hline BTM 9 & $1.2687^{\mathrm{c}, \mathrm{d}}$ \\
\hline
\end{tabular}

* Notasi yang berbeda menunjukkan hasil yang berbeda nyata dengan tingkat signifikansi 0.05

Cookies dengan perbandingan tepung beras, tepung tapioka, tepung maizena sebesar 65:30:5 menghasilkan kadar abu paling rendah dan perbandingan 55:30:15 menghasilkan kadar abu paling tinggi. Peningkatan jumlah tepung tapioka dan penurunan jumlah tepung maizena tidak menyebabkan perbedaan kadar abu sedangkan peningkatan jumlah tepung beras dan penurunan jumlah tepung tapioka menyebabkan penurunan kadar abu.

\subsection{Nilai Kalori}

Cookies berbahan baku campuran tepung beras, tepung tapioka, dan tepung maizena memenuhi nilai kalori Standar Nasional Indonesia biskuit (01-2973-1992) karena mempunyai nilai kalori yang lebih tinggi dari batas minimal sebesar $400 \mathrm{kal} / 100$ gram. Nilai kalori cookies tersebut antara 419.29-438.99 kal/100 gram (Tabel 8).

Tabel 8 Nilai Kalori Cookies Berbasis Campuran Tepung Beras, Tepung Tapioka, dan

\begin{tabular}{cc}
\multicolumn{2}{c}{ Tepung Maizena } \\
\hline $\begin{array}{c}\text { Jenis } \\
\text { Cookies }\end{array}$ & Nilai Kalori (Kal) \\
\hline BTM 1 & $438.9912^{\mathrm{d}}$ \\
\hline BTM 2 & $432.0100^{\mathrm{b}, \mathrm{c}}$ \\
\hline BTM 3 & $434.6874^{\mathrm{c}, \mathrm{d}}$ \\
\hline BTM 4 & $429.3334^{\mathrm{b}}$ \\
\hline BTM 5 & $431.1731^{\mathrm{b}, \mathrm{c}}$ \\
\hline BTM 6 & $419.2873^{\mathrm{a}}$ \\
\hline BTM 7 & $421.2303^{\mathrm{a}}$ \\
\hline BTM 8 & $421.6339^{\mathrm{a}}$ \\
\hline BTM 9 & $420.2777^{\mathrm{a}}$
\end{tabular}

* Notasi yang berbeda menunjukkan hasil yang berbeda nyata dengan tingkat signifikansi 0.05 
Cookies dengan perbandingan tepung beras, tepung tapioka, tepung maizena sebesar 60:25:15 memiliki nilai kalori paling rendah dan perbandingan 45:45:10 memiliki nilai kalori paling tinggi. Peningkatan jumlah tepung beras dan penurunan jumlah tepung tapioka tidak menyebabkan perubahan nilai kalori cookies. Begitu juga dengan penurunan jumlah tepung beras dan peningkatan jumlah tepung maizena tidak menyebabkan perubahan nilai kalori.

\section{Kesimpulan}

Cookies berbahan baku campuran tepung beras, tepung tapioka, dan tepung maizena memiliki kadar abu, kadar lemak, dan nilai kalori yang sesuai dengan Standar Nasional Indonesia produk sejenis yaitu biskuit. Sedangkan kadar protein, kadar serat kasar, dan kadar karbohidrat belum sesuai dengan Standar Nasional Indonesia biskuit.

Formulasi cookies yang dipilih berdasarkan kandungan kimia cookies yaitu campuran tepung beras, tepung tapioka, dan tepung maizena dengan perbandingan 65:30:5 karena memiliki kadar protein paling tinggi.

\section{Ucapan Terima Kasih}

Ucapan terima kasih kami sampaikan kepada pihak penyandang dana penelitian yaitu Universitas Ahmad Dahlan.

\section{Pustaka}

Adeyeye, S.A., dan J.O. Akingbala. 2015. "Quality Characteristics and Acceptability of Cookies From Sweet Potato - Maize Flour Blends", dalam Nutrition \& Food Science. Volume 45, 2015, 703-715.

Ana C. B. L., A. J. G. Pereira dan R. Gonçalves. 2004. "Flour Mixture of Rice Flour, Corn and Cassava Starch in the Production of Gluten-Free White Bread", dalam Brazilian Archives of Biology and Technology. Volume 47. No 1, 2014, 63-70.

Anonim $^{a}$. 2015. Statistik Konsumsi Pangan Tahun 2015. Jakarta: Pusat Data dan Sistem Informasi Pertanian, Sekretariat Jenderal, Kementrian Pertanian.

Anonim ${ }^{b}$. 2015. Laporan Akhir: Kajian Efektivitas Kebijakan Impor Produk Pangan dalam Rangka Stabilisasi Harga. Jakarta: Badan Pengkajian dan Pengembangan Kebijakan Perdagangan Kementerian Perdagangan.

Giuberti G, Fortunati P, Cerioli C, Gallo A. 2015. "Gluten Free Maize Cookies Prepared With High-amylose Starch: In Vitro Starch Digestibility and Sensory Characteristics", dalam J Nutr Food Sci. Volume 5, 2015, 424-428.

Luh, B. S. dan Yuan-Kuang Liu. 1980. Rice Flour in Baking, in Rice: Utilization. New York: Van Nostrand Reinhold.

Montes, Simone de Souza, L. M. Rodrigues, R.C.V. Cardoso, G.P. Camilloto, dan R.S.Cruz. 2015. "Tapioca and Rice Flour Cookies: Technological, Nutritional, and Sensory Properties", dalam Cienc. Agrotec., Lavras. Volume 39 No 5, 2015, 514-522. 
Rai, S., A. Kaur, dan B. Singh. 2014. "Quality Characteristics of Gluten Free Cookies Prepared From Different Flour Combinations", dalam J Food Sci Technol. Volume 51 (4), 2014, 785-789.

Risti, Y. dan A. Rahayuni. 2013. "Pengaruh Penambahan Telur terhadap Kadar Protein, Serat, Tingkat Kekenyalan dan Penerimaan Mie Basah Bebas Gluten Berbahan Baku Tepung Komposit (Tepung Komposit: Tepung mocaf, Tapioka dan Maizena)", dalam Journal of Nutrition College. Volume 2 No 4, 2013, 696-703.

Smith, W. H. 1972. Biscuit, Crakers and Cookies. London: Applied Science Publisher Ltd. Sultan, W. J. 1969. Practical Baking. New Jersey: Wiley. 